\title{
Is Asia a 'Post-Religional' society? \\ The Post-Religional Paradigm and its others**
}

\author{
A Ásia é uma sociedade pós-religional? \\ O Paradigma pós-religional e seus outros paradigmas
}

Daniel Franklin Estepa Pilario, C.M.*

\begin{abstract}
This article discusses the relevance and applicability of the 'post-religional paradigm' as proposed by EATWOT (Ecumenical Association of Third World Theologians) in the Asian contexts. It also inquires on how the Asian phenomenon and its interpretations relate to the crisis of religions in Western societies. It attempts to answer this problematic through four steps: a summary of the theological proposal and its relationship with the Western sociologies of religion; a search for a viable framework with which to understand religions in post-secular societies; discussion on the "discourses of Asia" and the corresponding view on religion; an elaboration of my preferred framework with some examples from the Asian situation. I argue that a viable theological proposal on post-religional paradigm should start from the analysis of how religious discourses and practices navigate with concrete socio-historical forces on the ground. Consequent to this view is the assertion that there is no universal sociology/theology of religion's development but multiple and complex religious discourses in specific contexts.
\end{abstract}

Keywords: Asian religions. Sociology of religion. Post-secular religions. Post-religonal paradigm

\section{Resumo}

Este artigo discute a relevância e aplicabilidade do "paradigma pós-religional", como proposto pela Associação Ecumênica de Teólogos do Terceiro Mundo (EATWOT) no contexto asiático. Também indaga sobre como o fenômeno asiático, e suas interpretações, está relacionado com a crise das religiões nas sociedades ocidentais. Busca responder a essa problemática em quatro etapas: um resumo da proposta teológica e sua relação com as sociologias da religião ocidental; a busca de um quadro viável para se compreender as religiões nas sociedades pós-seculares; a discussão sobre os "discursos da Ásia" e a visão correspondente sobre a religião; e a elaboração do meu quadro preferido com alguns exemplos da situação asiática. Defendo que uma proposta teológica viável no paradigma pós-religional deve começar a partir da análise de como os discursos e as práticas religiosas navegam com as forças sócio-históricas concretas da realidade. Em decorrência dessa visão pode-se afirmar que não há nenhuma sociologia/teologia universal do desenvolvimento da religião, mas múltiplos e complexos discursos religiosos em contextos específicos.

Palavras-chave: Religiões asiáticas. Sociologia da religião. Religiões pós-seculares.

Paradigma pós-religional.

Article received on November 03, 2014 and approved on March 04, 2015.

* PhD in Systematic theology at the Catholic University of Louvain, Belgium, is currently the dean of St. Vincent School of Theology, Philippines. Country of origin: Philippines. E-mail: danielfranklinpilario@yahoo.com.

**The author is indebted to the Center for World Catholicism and Intercultural Theology (CWCIT) of De Paul University (Chicago) for the Senior Research Fellowship it granted during which this article was written. Thanks to Maricor Baytion for her helpful comments and editorial suggestions.

Horizonte, Belo Horizonte, vol. 13, no. 37, p. 279-318, Jan./Mar 2015 - ISSN 2175-5841 


\section{Introduction}

We are experiencing the advent of a "post-religional" society, proclaims the proposal-hypothesis of the International Theological Commission of EATWOT Ecumenical Association of Third World Theologian¹ (EATWOT, 2012). The task asked of me in this article is to inquire "whether the post-religional interpretation of the current crisis of religion operates in the Asian context, at least in some sectors of society, if not in the majority of the population. What is its prognosis in Asia? How is this analysis related to the crisis in Western societies?" I would like to answer these questions in four steps. First, I will try to elaborate the proposal vis-àvis other parallel Western paradigms. Second, I will forward three different interpretations of the present phenomenon through some representative thinkers on religion. Third, I will explore the repercussions of these theories in the discourse of 'Asia'. Finally, in conclusion, I will expound e my preferred framework through some examples from Asian contexts.

\section{The Post-Religional Paradigm}

EATWOT's post-religional paradigm describes its theological proposal through a contemporary metaphor. As an airplane takes off and folds its wheels in, it begins to rely on a new and totally different system - that of its wings. It is so with humankind. As the old Neolithic religions cease to exist, human communities undergo a difficult adjustment to a totally different axiological system. "The duty of a responsible theology is to foresee these problems and try to accompany the inevitable 'transit' in which we already find ourselves."(EATWOT, 2012, p. 273).

We can summarize the theological proposal in four main points. First, religions have not always existed. Religion first appeared at the start of the Neolithic era when the hunters and gatherers began to settle in agricultural landscapes, thus, transforming their ways of life in new permanent territories. 
Second, Neolithic religions have recognizable characteristics , two of which are: (a) an imposed mythical epistemology on believers backed up by "divine revelation" as seen in its dogmas, morals and laws, turning the whole system into an ideologicalpolitical institution with absolute authority that demands full submission, and; (b) a monopoly over human thought and spirituality backed up by the "book" with its distinct interpretation of the world. How the EATWOT proposal defines religion clarifies these attributes: Religion is "socio-institutionalized configuration that human religiosity (spirituality) of all times adopted in the Neolithic [era], through which it has served as a fundamental system of programming and self-control of Neolithic agrarian societies." (EATWOT, 2012, p. 264). Third, the present society is in transition towards the "post-religional" context. Since religions are "constructed", they are not eternal. Neolithic religions fade away with the civilization that created it. Fourth, the post-religional paradigm is not only descriptive but also normative. Since dying is a difficult process, we need to help "religional religions" die well towards a death that gives life to others (ars moriendi). In practical terms, there is a need to reconvert religions' "symbolic patrimony" in order to adapt to new epistemological constellations. There is a need to help people feel that they are

free from 'religional' bindings [so as] to unleash our personal and collective fulfilment, to fully take responsibility for our decisions, our interpretation at our risk, without any restriction or supposedly external coercion, although worried to tune up to the Mystery that moves us. (EATWOT, 2012, p. 267).

The theological proposal has two accompanying caveats on: (a) the distinction between religion and spirituality, and; (b) the non-applicability of this paradigm to all religions. First, the proponents are careful to distinguish religion from spirituality. The terms used are crucial: the proposal is "post-religional" not "post-religious". While religion is contingent, spirituality is permanent. While religions come to exist at a certain time in history, spirituality is an intrinsic characteristic of homo sapiens from the start of their existence (EATWOT, 2012, p. 
268). ${ }^{2}$ This explains why in the post-religional context, resurgence and revival of spiritualities abound in what many contemporary thinkers call the 'reenchantment of the world'. Certain forms of religions go but spirituality survives. The second warning is that the post-religional paradigm does not apply to all religions. In this analysis, there are religions that have not undergone agrarian revolutions, thus, also not possessing Neolithic religion's specific hegemonic characteristics. What is contemplated here are animist religions and indigenous beliefs (including Hinduism) which do not display dogmatic-doctrinal dominance.

\section{Framing the Discourse in a Wider Context}

The theological proposal above is not at all novel in the field of theology and social sciences. I would like to situate this discourse from the perspective of the wider debate in the sociology of religions. First, the post-religional paradigm has affinities with the evolutionary theories of religion. Second, it is also related to the secularization debate in contemporary Western societies. In fact, the question whether this phenomenon is happening in Asia or not is in part a Western preoccupation. I will attempt to locate the post-religional paradigm in these discourses in order to better understand its underlying assumptions.

\subsection{Evolutionary Views of Religion}

In recent years, we have seen the emergence of evolutionary theories of religion, the most prominent proponent of which is the American sociologist, Robert Bellah. In his latest book, Religion and Human Evolution (2011),3 Bellah argues that religions evolve with human society as they adjust into its different stages: tribal, archaic and axial ages. Religious development moves from pure ritual

\footnotetext{
2 "[R]eligions would be a specific socio-cultural configuration in which spirituality of human beings has been expressed for some time, while spirituality would continue to be an essential dimension and a characteristic of the human being, that permanently and inevitably accompanies him [sic] since its emergence as a species." (EATWOT, 2012, p.268).

${ }^{3}$ This work that caps his academic career is a development of an earlier article on the same subject of religious evolution. Cf. BELLAH, 1964, p. 358-374. In another article, Bellah classifies religious evolution in five periods: primitive, archaic, historic, early modern, modern/contemporary - a periodization that was already present in the 1964 article. Cf. BELLAH, 1991.
} 
(tribal) to the mythical (archaic) and the theoretical (axial). As it goes through these phases, it conserves what has been developed so that "nothing is ever lost" in the process (BELLAH, 2014). Crucial to this development is the Axial age which makes religions universal, theoretical and critical. Axial religions eschew previous tendencies to dominate as they critique the repressive status quo and advance ethical ways of life. The four Axial civilizations (and religions) which Bellah discusses are Ancient Israel, India, China and Greece whose civilizations and literatures constitute a "breakthrough" in human thinking and cultures.

Other contemporary sociologists of religion follow Bellah's lead. In The Great Transformation Karen Armstrong (2007) also discusses the development of the Axial age as the foundation of our religious traditions. "During this period of intense creativity, spiritual and philosophical geniuses pioneered an entirely new kind of human experience."(BELLAH, 2007, p. xvi). Recovering this era leads us to important directions religions should tread in our times. Armstrong is clear on what these lessons are: personal responsibility and self-criticism to be followed by effective action and compassion. Contrary to religion's usual emphasis on doctrine, "what mattered was not what you believed but how you behaved."(BELLAH, 2007, p. xviii).

Bellah and Armstrong's focus on the Axial Age has been adapted from the periodization put forward by the German philosopher Karl Jaspers (1954, p. 98104; 1953, p. 24-26). Jaspers theorized four basic segments of history: the Promethean age (the use of language, the kindling of fire, the invention of tools); the ancient high civilizations in Egypt and Mesopotamia (5000-3000 BCE); the Axial Age (800-200 BCE); and the age of science and technology (medieval Europe). What is crucial is the third segment; it is "the axis in history", the pivotal age of civilization. This is the age of Confucius and Lao Tse in China; of the Upanishads and Buddha in India; of Homer, Parmenides, Heraclitus, Plato in Greece; of Zarathustra in Iran; and of the great prophets Elijah, Isaiah, Jeremiah in Palestine. All these developments grew independently of one another. Jasper 
argues that during the Axial age, humans became "aware of being as a whole, of himself and his limits... raised radical questions, approached the abyss in his drive for liberation and redemption... and experienced the absolute in the depth of selfhood and in the clarity of transcendence (JASPER, 1954, p. 99).

The evolutionary direction is common to EATWOT's post-religional paradigm and Bellah's (and Armstrong's) works. 4 Except for a change of names, Bellah generally followed Jasper's periodization in order to bring out his triple framework (play, myth and theory), the peak moment of which is the Axial period (BELLAH; JOAS, 2012). The post-religional paradigm, for its part, also adheres to this evolutionary scheme in its rough periodization from Paleolithic to Neolithic and beyond. These contemporary directions are not a new trend in the sociology of religion. Anthropological and sociological sciences both privileged this evolutionary worldview in the second half of the nineteenth century (TURNER, 2011, p. 285-301). That society (and its religions) develops from its "primitive" stages to its more "civilized" ones has been a common refrain from Auguste Comte to Herbert Spencer, from E. B. Tylor to J. G. Frazer.

Beyond their evolutionary commonalities, however, these two schemes (Bellah and the post-religional paradigm) move along divergent paths. First, Bellah traces the origins of religions to as early as the Big Bang, the emergence of life up to the point when homo sapiens learned to play, mimic rituals and narrate cosmic and cultural myths. In Bellah's reflection, all these are stirrings of religion as their "core processes" are conserved and carried over to the next stage of development (JOAS, 2012).5 The post-religional paradigm, on the other hand, thinks that even as spirituality/religiosity is co-extensive with humanity, religions only began to be practiced during the Neolithic phase when humans started to

\footnotetext{
${ }^{4}$ On Bellah's evolutionary religious paradigm, see WUTHNOW, 1992. Bellah, however, qualifies his position vis-à-vis the evolutionary paradigm. It is not about the evolution of religion itself as the place of religion in the evolutionary process, thus, the revision of the title of the work from "Religious Evolution" (BELLAH, 1964) to "Religion in Human Evolution" (BELLAH, 2011). Cf. JOAS, 2014.

${ }^{5}$ In an interview, Bellah explicates what is meant by the formula "nothing is ever lost" which keeps reappearing in his text. "It again goes all the way back because the subatomic particles in our body were produced by the Big Bang, so parts of our body are 13.7 billion years old. Every cell in our body is genealogically descended from single cell organisms, which we call familiarly "bacteria." So even biologically we haven't lost anything. We've developed enormously new complex structures, but on the basis of things that remain fundamental for us all around." This is true for cultures as it is for religion - from the way we deal with the body, with our myths and narratives, with our theological and ethical theories (JOAS, 2012).
} 
settle in agrarian societies. In short, there was a (long) time when religions did not exist at all. While Bellah's positive and evolutionary worldview assumes everything toward the next stage, the post-religional paradigm feels obliged to discard Neolithic religions when this civilizational phase is over. While Bellah's vision is cumulative, the post-religional view consists of religio-cultural breaks and shifts. This difference points to a larger epistemological debate on the notion of scientific and cultural development. On the one hand, modern science has always been viewed through the lens of evolutionary progress. Scientific, cultural and intellectual progress developed through an evolving, continuous and cumulative process. Like Bellah, "nothing is ever lost". Each new discovery leads to the unravelling of the nature and truth of reality. On the other hand, Thomas Kuhn attacked this evolutionary idea and argued that there is "no coherent direction of ontological development" in science; one does not approach truth in a cumulative manner. Newton is not a development of Aristotle and Einstein is not an evolution of Newton. In fact, "Einstein's general theory of relativity is closer to Aristotle than... to Newton." (KUHN, 1970, p. 206-207). Kuhn thinks that science moves more through "revolutions" than evolution. In crisis moments, a new paradigm appears which provides a better explanation for new scientific, historical and cultural constellations. This alternative paradigm does not build on old data; rather, scientists "work in a different world" which is incommensurable with the old. Science is thus not cumulative. When a new paradigm appears, the previous one becomes obsolete. Thus, the phenomenon of the "dying of religions" in the post-religional paradigm is nearer to Kuhn's notion of paradigm shifts than to Bellah's.

A second observation follows the first. While Bellah views the Axial age as a pivotal and positive development from which contemporary discussion needs to learn, the post-religional paradigm assumes that the Axial age only reinforces the authoritarian and hegemonic tendencies of Neolithic religions. These observations are crucial because they point to two divergent views with which religions are seen in these two paradigms. For Bellah and other thinkers like him, religion understood 
as mimetic, mythic and theoretic meaning-making has always been there from the beginning and just needs to be recovered in order to help us answer questions of our time. In contrast, the post-religional programmatic scheme hopes that these religions will fade and die so that new liberating forms of spiritualities can arise. We shall come back to engage these evolutionary paradigms in a discussion below.

\subsection{Religions and Secularization}

EATWOT's post-religional paradigm can also be read alongside the ongoing lively debate on secularization and post-secularization in Western societies. The words of the proposal-hypothesis sound ambivalent but a closer reading reveals a parallel analysis.

The present crisis is not due to secularisation processes, or to a loss of values, or to the dissemination of materialism or hedonism (blaming interpretation usually held by religions' officers), neither to the lack of testimony or to the moral scandals of religion, but to [the] birth of a new cultural situation, that puts an end to the radical transformations of the knowledge, axiological and epistemological Neolithic structures, transformation that started with the scientific revolution in the XVI century, the Enlightenment of the XVIII century and the various waves of industrialisation. The symptoms that this gradual transformation produces appear in ways such as certain diffuse agnosticism, loss of epistemological ingenuity, a more accentuated critical sense, a more utilitarian conceptualisation of religions as a service to the human being instead of receptors of full loyalty from their members, the disappearance of the idea of a "unique true religion" and a revealed moral (EATWOT, 2012, p. 270).

Despite its denial that the crisis of religion is not a consequence of secularization processes, the "radical transformation" of "axiological and epistemological neolithic structures" starting with scientific revolution, Enlightenment and industrialization which the post-religional paradigm identifies as reasons are in fact parallel to the secularization theories that date all the way to the classical sociologists like Durkheim or Weber and contemporary thinkers like Peter Berger, Bryan Wilson or Steve Bruce. According to these authors, there are several processes that make possible the retreat of religions in modern society: individualism, rationalization, bureaucracy, functional differentiation and religious 
pluralism (WARNER, 2010). The deterioration of the conscience collective in modern societies as analyzed by Durkheim brings about individualism and diminishes the practice of communal religion. Modernity's "iron cage of reason" (bureaucratic rationality) according to Weber leads to efficient but also impersonal systems that "[reduce] the worker to a cog in this bureaucratic machine." (WEBER, 1978, p. lix). It also demolishes "the authority of magical powers... which ultimately challenges all systems of belief." (WEBER, 1991, p. xxiv). Max Weber's "disenchantment of the world" is parallel with what contemporary thinkers like Peter Berger call the dissolution of the "sacred canopy" that provides a common frame within which "all of social life receives ultimate meaning binding on everybody."(BERGER, 1967, p. 134). Several contemporary authors follow Berger's lead in proclaiming religion's death. 6

But the secularization thesis is not without its critics. Many authors argue for the resurgence of religion in postmodernity.7 Berger himself recanted his earlier 'secularist' position in The Sacred Canopy to the signals of the supernatural in The Rumor of Angels (BERGER, 1969). He now thinks that "secularization may not be as all-embracing as some have thought"; it is not absolute and unstoppable (BERGER, 1969, p. 30). Ordinary life occurrences point us to transcendence ("the beyond in our midst"): our propensity for order, play and humor, sense of hope, capacity for moral outrage, etc. This post-secular discourse of the return of religion has wide and diverse expressions ranging from the denial of secularization to reenchantment with art and cultures, from reappearance of religion in public life to its engagement with politics, philosophy and theology. 8

How does the post-religional paradigm handle the secularization debate? It manages it by distinguishing religions from spirituality/religiosity. It believes that agrarian-neolithic religions fade but spirituality is universal.

\footnotetext{
${ }^{6}$ For an updated account of the secularization debate, see WARNER, 2010.

7 See KEPPEL, 1994; GREELY, 2003; THOMAS, 2005; MARTIN, 2002.

${ }^{8}$ Another good overview of the post-secular reflection on religions is found in BECKFORD, 2012, p. 1-19; BERGER, 1999, p. 1-18.
} 
Religions are forms, historical, contingent, and changing, while spirituality is a dimension that constitutes humanity, permanent, and essential to the human being. Spirituality may be experienced within or outside religions. We could do without religions, but we will never be able to dispense with human being's dimension of transcendence (EATWOT, 2012, p. 266).

This assertion finds parallel expressions in some US-based groups that call their movement "spiritual but not religious" (SBNR). 9 Mostly composed of young people (72\% of Generation $\mathrm{Y}$ and Millennials), unchurched and spiritual eclectics, SBNR bifurcates religion and spirituality into public and private, respectively. Consequently, the privatization of belief makes institutional affiliation no longer necessary.

Its European counterpart is called believing without belonging. Gracie Davies who writes quite extensively on this issue argues that there is a gap between the hard and soft indicators of religious life in Europe (DAVIE, 1994; 2000). Both 'believing' and 'belonging' have hard and soft dimensions.

For example, if you ask European populations - and here I'm generalizing - do you believe in God, and you're not terribly specific about the God in question, you'll get about 70 percent saying yes, depending where you are. If you say, do you believe that Jesus Christ is the son of God, you'll get a much lower number. In other words, if you turn your question into a creedal statement, the percentages go down. The looser your definition of belief, the higher the percentage of believers (DAVIE, 2005).

The same is true with belonging. In terms of hard indicators like weekly church attendance, the response would be less. But when the notion of belonging is softened, as when they are asked $\mathrm{r}$ about their preferred place for funeral services, many would stick to their church's affiliation. Generally, in Europe, "[t]he historic churches are public utilities, and you expect public utilities to be there when you need them." (DAVIE, 2005). This prompts another author to reverse the formula: belonging without believing (HERVIEU-LÉGER, 2004, p. 101-119).

\footnotetext{
${ }^{9}$ See FULLER, 2001; ERLANDSON, 2000; and "Examining the Growth of 'Spiritual but not Religious'," The New York Times, July 18, 2014 (OPPENHEIMER, 2014)..
} 
In short, while EATWOT's post-religional proposal hails the death of religions in consonance with secularization theories, it also welcomes different expressions of religiosities as forms of the new cultural configuration together with the post-secular discourses. Unlike the post-religional paradigm, however, not all post-secular discourses clearly distinguish religion from spirituality (i.e., with the religions 'dying' and spiritualities slowly emerging). While the US version maintains the public-private spaces for religion and spirituality respectively, religions do not actually disappear. Traditional religions continue to exist though no longer popularly practiced in public by the majority of the members. The European experience also strategically retains public religions when these become quite helpful for the "rainy days", as it were. Moreover, secular public rituals like royal weddings or World Cup finals, most of which are well-attended, also take on new 'religious' forms that demand devout, almost fanatical, allegiance.

Let me summarize my arguments thus far. The plot has continually thickened in the secularization debate and the post-religional paradigm is complicit with it. Originally, the secularization thesis purported to have an evolutionary, universalist and progressive inevitability. With the coming of modernity, religions were envisioned to eventually disappear. Atheism was supposed to be the end game. But it is precisely this modern prediction that is put into question by postsecular discourses. Instead of being disenchanted, the world is in fact reenchanted. Instead of being secularized, it is in fact desecularized. Not only are there multiple "modernities", there are also multiple "secularities" that bring about multiple "religious identities". There has been no one direction. ${ }^{10}$ Religions did not undergo a radical break caused by one local experience of European Enlightenment since there were as many modernities as there were cultures. As modernities interacted with religions, both transformed each other such that a part of each died

\footnotetext{
${ }^{10}$ José Casanova gives this insightful observation: "In our global age, it has become increasingly evident that European secular developments are not a universal norm for the rest of the world; that, as the rest of the world modernizes, people are not becoming more secular like us, but are becoming more religious - or, actually, they are becoming simultaneously both more secular and more religious, which of course only confuses our binary categories. But once it becomes obvious that the secularization of Europe is, comparatively speaking, rather exceptional, the old theory that explained Europe's secularity in terms of its modernity is no longer plausible." (CASANOVA, 2013, p.54)
} 
and another part arose anew. Or, better still (and this point differs from the postreligional praradigm), maybe there was no dying and rising, but instead a mutual negotiation and transformation in differing contexts. Some call the present moment a "twilight"; others think of it as the "dawn" of human experience (CASANOVA, 2010, p. 265-281). Some call it "decline"; others call it "revival" or "resurgence" of new religions.

From the perspective of the Western experience of monotheistic religions, this polytheistic phenomenon is viewed either as "crisis" of religions (as the postreligional paradigm calls it) that causes upheaval or it is a trend that is so novel and postmodern which calls for some celebration. But for non-Western peoples, immersed as they are in pluralist and multi-religious universes, what is happening in the West looks like "the old state of affairs." (CASANOVA, 2006). It has always been this way ever since in their own contexts. Whichever view one takes, however, depends upon the theoretical paradigm one adapts vis-à-vis both religion and secularity. This brings me to the next point.

\section{Theorizing Religions in a Post-Secular Society}

However the present situation is called, all descriptions point to a "postsecular" society. It is this phenomenon that preoccupies the contemporary academic scene. While the EATWOT theological proposal calls it 'post-religional', some authors calls it 'post-secular'. Both the post-religional paradigm and (post)secular theories trace this development to the beginning of Enlightenment and the modern age. The present state of religious resurgence, i.e., the "rumor of angels" in the secular city, is viewed either as a break away from or as a radicalization of previous stages of development. What frameworks do contemporary thinkers use in order to understand this post-secular phenomenon? I can recognize three general directions: (a) return to religion in secular modernity; (b) dialectical confrontation between modernity and religion; and (c) analysis of actual practices in their power-laden contexts. I will try to elaborate these directions by discussing some selected thinkers in order to bring out what for me is 
a viable framework in the understanding of this post-religious/post-secular phenomenon in the Asian context.

\subsection{Return to Religion}

The first position is heavily forwarded by the Radical Orthodoxy group with John Milbank as its representative thinker. His influential book Theology and Social Theory (MILBANK, 2006) ${ }^{11}$ attempts to dismantle the works of modernity in secular politics, capitalist economy, sociology, dialectical philosophy and postmodernity (all offspring of the Enlightenment) in order to recover the displaced Christendom and its offer of absolute ontological peace. Milbank begins his narrative with a programmatic "once upon a time" phrase:

Once there was no secular. And the secular was not latent, waiting to fill more space with the steam of the 'purely human', when the pressure of the sacred was relaxed. Instead there was the single community of Christendom with its dual aspects of sacerdotium and regnum (MILBANK, 2006, p. 9).

Against the secularization thesis, Milbank thinks that society has no purely human dimension waiting to be uncovered, obscured as it is with the medieval religious hegemony. He rightly argues that the "social" of modern social theory "was in itself as unreal, unhistorical and quasi-theological category."(MILBANK, 2006, p. xii). In agreement with post-secular thinkers, Milbank contends that the secular actually needed to be invented, constructed and imagined starting from Hugo Grotius's etsi Deus non daretur to the modern sociological project of "disenchantment". Milbank maintains that the secular has "positioned" theology. "If theology no longer seeks to position, qualify or criticize other discourses, then it is inevitable that that these discourses will position theology." (MILBANK, 2006, p. 1). His postmodern project thus was a Christian attempt to recover religion from

\footnotetext{
${ }^{11}$ A whole group of theologians called Radical Orthodoxy can be grouped together with Milbank under this heading (return to religion). Cf. MILBANK; PICKSTOCK; WARD, 1998; MILBANK; OLIVER, 2009. For my full analysis of Milbank's and Radical Orthodoxy's postmodern project, see PILARIO, 2005.
} 
such displacement in modern times, or to use Loughlin's metaphor, it is one hero's "quest of a stolen crown". Once upon a time, theology was the queen of sciences. But the crown was stolen from her by modern social theory. It is time to recover it (LOUGHLIN, 1992).12 Even as Milbank thinks his position is in fundamental agreement with that of Charles Taylor's in his analysis of the secular age, he (unlike Taylor) still longs for a possible return of Christendom in a global scale. "One could therefore optimistically conclude that only a more benign, more festive Christianity could ever hope to re-establish a new and now global Christendom." (MILBANK, 2010, p. 82). I have shown elsewhere why Milbank's postmodern theology is in reality a nostalgic return to the premodern and medieval Christendom. (PILARIO, 2005).

But Milbank is not alone. He aligns his work with the theological project of Joseph Ratzinger, then to become Pope Benedict XVI. Though Ratzinger is more nuanced than Milbank on the relationship between faith and political reason by saying that both reason and faith have their own pathologies (HABERMAS; RATZINGER, 2006), he also believes that the Christian's special relationship to the 'transcendent truth' through their faith in Christ makes them avoid all modern political totalitarianism as "they always have a Lord, a task, a standard, that transcends the party and its norms." (RATZINGER, 2009, p. 56). In the end, the common thread that runs in the minds of both thinkers (and in agreement with the secularization thesis) is that the hegemonic dominance of modern secular theory is responsible for the decline of religion. However, unlike the secularization theory which sings dirges of religion's demise, Milbank (and Ratzinger) intends to resurrect religion's influence on its own terms in our post-secular society since it is only this faith that has affinity to truth.

\footnotetext{
12 "Once upon a time, it was theology that wore the crown, theology that carried out most of the fundamental reading of all other interpretations and all other social formations... It was the master narrative. Stolen by secular reason, and worn as 'social theory', the master-narrative is now sought by its earlier owner." (LOUGHLIN, 1992, p. 366).
} 


\subsection{Dialectical Confrontation}

Unlike the first position, the second direction represented by Jürgen Habermas and Charles Taylor confronts modernity head-on and proposes a dialectical interaction with it. Habermas was responsible for placing the term "post-secular" on the academic screen (HABERMAS, 2008).13 In his earlier works, he rejoiced in the fact the communicative rationality in the secular public sphere has replaced religion or national sentiments (its irrationality and fanaticism included) as the integrating factor of the social body. In recent works (HABERMAS, 2006; HABERMAS, 2008; HABERMAS, 2010), however, he argues for a dialogue between secular reason and religions, recognizing that both religious and secular mentalities help in the building of a humane society. In this updated view, bringing religious discourse into the public sphere not only makes religious people feel "included", but also enlists religious resources in the forging of public life. For this dialogue to happen, religious citizens should be able to accept the natural conditions of modern society, e.g., pluralism, the rule of law, the authority of science, and others. Believers should also be able to translate their religious language into an understandable secular idiom that can resonate in the public sphere. The secularists, for their part, also need to acknowledge that religions possess some truth as their own contribution so social emancipation. "Secular citizens are expected not to exclude a fortiori that they may discover, even in religious utterances, semantic contents and covert personal intuitions that can be translated and introduced into a secular discourse." (HABERMAS, 2008, p. 29). This complementary learning process frees people from their religious and cultural closed universes so that all citizens "mutually recognize one another in civil society as members of one and the same political community." (HABERMAS, 2008, p. 22-23).

\footnotetext{
${ }^{13}$ For the conversation between Ratzinger and Habermas on religion and modernity, see HABERMAS; RATZINGER, 2006. For a critical commentary on the work of Habermas on religion, see CALHOUN; MENDIETA; VANANTWERPEN, 2013.
} 
Charles Taylor's celebrated work $A$ Secular Age (TAYLOR, 2007)14 pushes this argument to its consequences. Although Taylor acknowledges his affinity with Milbank and the Radical Orthodoxy project, unlike Milbank, Taylor does not wish to turn the clock back in nostalgia. He analyzes secularity and searches within it the possibility of transcendence. While Habermas stops in acknowledging the possibility of truth-contents of religious resources, Taylor sees the possibility of transcendence in what he calls the "immanent frame". Or, to combine images from previous authors, Taylor believes that the "rumor of angels" can in fact be heard within the "secular city". One commentator calls Taylor's position as "immanent transcendentalism". (MCLELLAN, 2010, p. 52-56). Against modernity's exclusive humanism or closed immanence, Taylor argues for something "beyond": beyond human flourishing, maybe a higher power which we call "God" or an extension of our life beyond birth and death (TAYLOR, 2007, p. 20). Beyond Milbank's exclusive Christendom, Taylor is also open to the presence of transcendence in Hindu, Muslim and Buddhist contexts. Against Habermas, however, Taylor refuses to use the term 'post-secular'. One of the original contributions of his work is his notion of Secularism 3: "a move from a society where belief in God is unchallenged and indeed, unproblematic, to one in which it is understood to be one option among others, and frequently not easiest to embrace." (TAYLOR, 2007, p. 3). For Taylor, secularization thus does not only refer to the decline of religious practice or the consignment of religion into the private (which is the main tenet of main secularization theories), but also to the "conditions of belief", that is, the fact that "belief" comes to be seen as one mere option among the many. If secularization is understood this way, the word "post-secular" already becomes superfluous if used to describe the present situation as the term is already incorporated into secularism's meaning (WARNER, 2010, p. 22-23). I am aware that summarizing the complex content of Taylor's magisterial book in a few paragraphs does not do justice to this voluminous work of a lifetime. But identifying the main directions of its arguments can help us assess its viability in our theorizing of religions in the Asian contexts. I will come back to the assessment below but let me just point out

\footnotetext{
${ }^{14}$ For a critical commentary on this work, see WARNER; VANANTWERPEN; CALHOUN, 2010.
} 
one obvious lacuna in Taylor's work: his silence about other cultures beyond the European-North American contexts and other religions beyond Latin Christendom, thus, giving the impression that the otherwise eloquent work is an ethnocentric discourse.

\subsection{Analyzing Discourses in Context}

The third position vis-à-vis the post-secular phenomenon is the genealogical method done by Talal Asad, a New York-based anthropologist with Saudi Arabian and Pakistani roots. Two of his crucial works that bring about his analysis are the Genealogies of Religion (ASAD, 1993) and Formation of the Secular (ASAD, 2003). While Milbank proclaims that the 'secular' is an invented category, Asad argues that 'religion' is also a constructed concept. Not that religion did not exist ever since but that the notion of 'universal' religion is a modern category and is not helpful at all in the realistic analysis of its movement in the social body. Let me summarize Asad's complex work in three crucial points: (a) universalist and transhistorical notions of "religion" are not viable; (b) "modernity" and "secularity" are not univocal and homogenous realities, and; (b) in order to understand both, we do not analyze universal "values and meanings", but particular "religious" and "modern" sentiments and practices in their actual power-laden social and historical contexts.

First, Asad takes issue with Clifford Geertz's universalist but also dualistic definition of religion as external "systems of symbols" which effect internal "moods and motivations" in the participants (GEERTZ, 1973). This interpretivist and psychological approach to religion, Asad claims, is forgetful of the fact that power creates religion.

How does power create religion? To ask this question is to seek an answer in terms of the social disciplines and social forces which come together at particular historical moments, to make particular religious discourses, practices and spaces possible... Universal definitions of religion hinder 
such investigations because and to the extent that they aim at identifying essences when we should be trying to explore concrete sets of historical relations and processes (ASAD, 1983, p.252).

Transhistorical notions of religion, because of its universalizing and essentializing mode, ${ }^{15}$ detach us from the cognition of the domains of power inherent in religious practices and discourses.

Second, the notion of the "secular" and the "modern" prevalent in secularization theories and post-secular discourses also falls into the same trap. For instance, "modernity" (which is often contrasted with "tradition") has always been understood as homogeneous reality with some common identifiable elements that hang together. In terms of social structures, these would be elements of industrialization, secularization, democracy. Modernity is also identified as one philosophical project from Descartes to Habermas. Or, it consists of specific psychological or aesthetic experiences (e.g., Kant's universal taste and aesthetic judgment, etc.). And since these aspects of Western modernity have come together historically in Europe (and North America), "all these things must and should fall together in the rest of the world." (ASAD, 1996). ${ }^{16}$ Like religion, values then become essentialized and get to be contrasted with each other, e.g., "modernity" (progressive, evolving and scientific) vs. "tradition" (unchanging, repetitive and non-rational), and the mixing of the two in any social order is viewed as either as "pathological" (reactionary) or "still in the process" of development towards the Promised Land of modern Paradise. A parallel problem is found in the contrast between the "secular" and the "sacred". Asad argues that the secular is not a development of or a break from the religious because the secular and the religious have always co-existed in time. (ASAD, 2003). ${ }^{17}$ In a sense, modernity and

\footnotetext{
${ }^{15}$ The movement towards universalization of religion is traced by Asad to Immanuel Kant: "But there can only be one religion which is valid for all men and at all times. Thus the different confessions can scarcely be more than the vehicles of religion; these are fortuitous, and may vary with differences in time or place." (KANT, 1991, p. 114; apud ASAD, 1993, p. 42).

${ }^{16}$ See also ASAD, 2003.

17 "The secular, I argue, is neither continuous with the religious that supposedly preceded it (that is, it is not the latest phase of sacred origin) nor a simple break from it (that is, it is not the opposite, an essence that excludes the sacred). I take the secular to be a concept that brings together certain behaviors, knowledges, and sensibilities in modern life. To appreciate this it is not enough to show that what appears to be necessary is really contingent - that in certain respects the 'secular' obviously overlaps the 'religious'. It is a matter of showing how contingencies relate to changes in the grammar of concepts - that is, how the changes in concepts articulate changes in practices." (ASAD, 2003, p. 15).
} 
tradition (as with the secular and the religious) are not mutually exclusive states of society's cultural evolution but different aspects of its grounded historicity.

Third, Asad thus proposes an analytical approach which begins not by identifying the prevalence or absence of some universal essences, symbolic meanings or transhistorical values, but "by asking what are the historical conditions (movements, classes, institutions, ideologies) necessary for the existence of particular religious [and other] practices and discourses." (ASAD, 1983, p. 252). Thus, in analyzing rituals, beliefs or practices, there is a need to reconstruct the actual historical conditions that make possible the existence of these realities and how social power sanctions some meanings and marginalizes or excludes others. This means that what is 'religious' and what is 'secular' can never be understood outside the actual context of social forces that constitute it. Until this happens, Asad argues, "We shall not make much headway in understanding agency." (ASAD, 1993, p. 167). True to his non-essentializing project, Asad decouples the binaries with which 'religion' has been paired in prevalent scientific discourses: sacred vs. profane, transcendent vs. immanent, religious vs. secular. These binary categories are constant in most theories we have discussed above from Bellah to Berger, from Milbank and Ratzinger to Habermas and Taylor. If what is 'religious' or 'secular' depends on the socio-historical powers that construct them at specific historical moments, these binaries do not lend themselves to universal meanings, thus, making it impossible to inquire about their constant interrelation outside of their concrete social conditions. Asad can doubtlessly agree with José Casanova's observation:

The sacred tends to be immanent in pre-axial cultures; the transcendent is not necessarily 'religious' in some axial civilizations. The secular is by no means profane in our secular age. One only needs to think of such sacralized secular phenomena as nation, citizenship and human rights (CASANOVA, 2009, p. 1062-1063). ${ }^{18}$

\footnotetext{
${ }^{18}$ Though there is a debate between Talal Asad and José Casanova, I think their positions are complementary as Casanova himself acknowledges. Cf. CASANOVA, 2006, p. 12-30.
} 
To summarize, we have outlined three approaches to understand the decline and resurgence of religions in post-secular society. The first position is critical of the modernization-secularization process as it causes the retreat of religion. Milbank's project (and to some extent Ratzinger's) is to recover religion's (understood as Christianity) leading position it once had in the social space. Even as it effectively analyzes the power of modernity to impose its hegemony over religion and to enlist the faith towards its secularist project, its option to re-assert religious hegemony is not viable in contemporary pluralist and global universes. Worse, it can be seen as a last-ditch attempt to regain a hopelessly losing battle to re-establish once more a new metanarrative that will outplay the rest. The second position seeks a direct confrontation with modern secularity proposing an honest negotiation between religious and secularist worldviews (Habermas) at the same time seeking transcendence in the "immanent frame" (Taylor). Though laudable, this originally European Enlightenment project also seeks to impose its modern narrative on the rest of the world. In short, it is saying, if the West has undergone this, the rest of the world will follow suit. The third position refuses to essentialize the social realities it analyzes - be it religion, secular modernity, etc. Asad believes that these phenomena, their concrete practices and their narratives are constructed, products as they are of intersecting power relations in specific historical contexts. If we want to assess the state of religion vis-à-vis modernity, for instance, we need to appraise its specific socio-historical conditions of possibility. I feel that this last position is crucial to the question posed at the start: "Is Asia a post-religional society?"

\section{The Discourse of Asia}

Despite the theories' divergences, (post)secularization, as we have shown above, is very much a Western debate. The main task of this article is to investigate whether this is also an 'Asian' phenomenon. ${ }^{19}$ But which Asia? There are practically

\footnotetext{
${ }^{19}$ I have used this specific mapping of the 'Asian' discourses in a previous article and adjusted the discussion to fit the present problematic. Cf. PILARIO, 2007, p. 24-53.
} 
two ways of looking at Asia: the imperialist discourse of "Orientalist Asia" and the "Asianist Asia" of the Asian values discourse. The answer to the question of postreligionality of Asia heavily depends on the position one takes in the "discourse of Asia".

\section{1 (Neo)Orientalist Asia: Imperial Discourse}

The 'idea of Asia' did not first come from Asia. It was a European invention (HUI, 2005; HUI, 2006; MILNER; JOHNSON, 1997; MCLNNES, 1998). In the 18 ${ }^{\text {th }}$ and $19^{\text {th }}$ century, the human sciences (linguistics, historiography, political philosophy, geography, etc.) upheld a teleological vision of history consistent with modern enlightenment and the colonial project. The idea of Asia that this project produced is what I call 'Orientalist Asia'. 'Orientalism,' as Edward Said describes it, is the imperial West's manner of writing about the Orient - its colonized other (SAID, 1995). The main problem of Orientalist discourse is its essentialized binarism - a way of describing the East as a total contrast of the West. ${ }^{20}$ Thus, thinkers like Adam Smith, Hegel and Marx viewed Asia as a binary opposite of (but also as mere preparation for) the achievements of Europe: Asian multi-ethnic empires against the European sovereign monarchy; Oriental political tyranny vs. the Western rationalized juridical system; Asian agrarian mode of production vs. European cosmopolitan-urban trading. Since Europe was 'the end of history', Asia is incorporated to its 'beginnings', thus, also relegating it to the realm of 'prehistory'. In his Philosophy of History, Hegel, for instance, writes:

The history of the world travels from East to West, for Europe is absolutely the end of history, Asia is the beginning... The East knew and to the present day knows that One is free; the Greeks and the Roman world, that some are free; the German world knows that All are free. The first

\footnotetext{
20 "From its earliest modern history to the present, Orientalism as a form of thought for dealing with the foreign has typically shown the altogether regrettable tendency of any knowledge based on such hard-and-fast distinctions as 'East' and 'West': to channel thought into a West and East compartment. Because this tendency is right at the center of Orientalist theory, practice and values found in the West, the sense of Western power over the Orient is taken for granted as having status of scientific truth." (SAID, 1995, p. 46).
} 
political form, therefore, which we observe in History is Despotism, the second Democracy and Aristocracy, the third Monarchy (HEGEL, 1956, p. 103-104)

In the Wealth of Nations (SMITH, 2000), Adam Smith laid out the same teleological view when he mapped out civilization into four stages - i.e., hunting, nomadic, agricultural and commercial epochs. The North American Indians were in the hunting stage - the "lowest and rudest state of society". The Tartars and Arabs (Orientals) belong to the nomadic stage; the Greeks and Romans to the agricultural stage (although he also mentioned China in this level). History thus ended with Europe as it reached the epoch of modern commerce. Karl Marx was no exception. He also mapped out history into four phases - Asiatic, primitive, feudal and capitalist stages. In Asia, there is no revolutionary force to propel the proletarian revolution. With no private ownership of land, there will be no social class, thus, no class conflict which for Marx is the motor of history. In Asia, history thus is 'stagnant' as its culture. But all these generalizations about Asia were already a product of a long intellectual history of European modern thinking about its dominated 'other': the prevalence of common ownership of land, the lack of legal structures, predominance of religion, absence of aristocratic culture, prevalence of slavery, isolated village life, importance of agriculture over industry, stagnant history (ANDERSON, 1979). ${ }^{21}$ Max Weber, despite his toying around with Confucianism as the Asian counterpart of the Calvinist ethic, still thinks that the Asian mind is typically arbitrary and unstable as contrasted to the rational character of Western law, science and industry (TURNER, 1974). It is this essentialist idea of an 'unchanging', 'religious' and 'mysterious' Asia that has become a haven for Western romantics, utopians and vegetarians in quest of an alternative lifestyle or peace of mind - still a part of a continuing Orientalist discourse.

\footnotetext{
${ }^{21}$ The contrast between 'Europe' and 'Asia' has long been a feature of the European imagination. Arnold Toynbee writes that the Greek historian Herodotus already accounted for the long-standing rivalry between 'Europe' and 'Asia'. See TOYNBEE, 1954. In many other European writings, 'Asiatic' means 'splendor', 'vulgarity', and 'arbitrary authority'. Europe was correlated with science, weaponry and Christianity while 'Asia' was connected with ornate vestments, camels and monkeys. The philosophe Montesquieu links Europe with progress and Asia with stagnation. Cf. HAY, 1957.
} 
Are these early modern conceptions still being reproduced in contemporary discourses? Is there such a thing as 'neo-Orientalist Asia'? In popular culture, contemporary mass media (e.g., films, TV news reporting, print media, etc.) is awash in neo-Orientalist images. ${ }^{22}$ During the Asian 'economic crisis' in the late 1990s, the public was bombarded with an image of Asia as 'naturally' linked to "corruption, inefficiency, incompetence" - attitudes which are incompatible with Western capitalist ethos. This supposedly was the cause of their downfall. The same Orientalist but also racist perspective has been reinforced in the political field after 9/11 bombing when Asians - mainly of Islamic affiliation - are casually described as 'terrorists'.

I argue that the same 'Orientialist' direction can also be discerned in the sociological discourses of religion. The post-religion paradigm, Bellah's (and Armstrong's) accounts of religious development and the secularization debates all share in the evolutionary framework which when applied to Asian religions necessary bears out an 'Orientalist' analysis. Let us mention three observations. First, Bellah's concept of "religion" throughout different stages of humankind's cultural development (that is, from tribal to archaic to axial eras) is rightly pointed out by José Casanova's as essentialist and universalist (CASANOVA, 2012). The Latin category religio, which was coined only a little over two thousand years ago, has constantly changed in the whole of Western history. Most non-Western cultures do not even have an indigenous equivalent term so much so that neologisms had to be invented in order to designate an imposed foreign category (e.g., shukyo in Japanese or zongjiao in Chinese). But hardly does Bellah's analysis hint at this difficulty. Moreover, human religious sensibilities have been modified, altered, revised or subverted throughout the ages depending on their encounter with power and cultures, but the same category called "religion" - no matter how contradictory or equivocal, in the different phases of the evolution - comes to be identified as the same essential reality in Bellah's discourse.

\footnotetext{
${ }^{22}$ See analysis of films Gunga Din (1939) and Blood Oath (1988) and samples of contemporary news reporting as expressions of neoOrientalism in BIRCH; SCHIRATO; SRIVASTAVA, 2001, p. 1-13; also IWAMURA, 2011.
} 
Second, the evolutionary worldview inherent in secularization theories more obviously exhibits an Orientalist view of Asian religions. The "mystic East", the "mysterious Asia" or the "Oriental spiritual civilization" are but just few categories used to describe the Asian religious phenomena (KING, 1999). These essentialist categories of Oriental religions are posited vis-à-vis the West. While the East is still mystic, traditional and religious, the West is already scientific, progressive and rational - reminiscent of Comte's evolutionary categories ('theological', 'metaphysical' and 'positivist' civilizational phases) or of James Frazer's 'magic', 'religion' and science'. The running argument is this: when Asia has reached a specific stage of modern development, what happened in the West with regard to religion will also come about.

Third, we have seen how the secularization thesis has been disproven even by Western post-secular authors themselves. But even these post-secular discourses exhibit ethnocentric and universalist tendencies. Habermas thinks that the 'post-secular' is another historical phase that now accommodates religious voices in the public space, thus, also normative for the whole of history. The secularist progression of consciousness

\begin{abstract}
that sees modernity - whether or not finished and whether a project or an achievement - as involving a linear, and irreversible, progress away from the 'premodern'. This linear temporality is reflected in the - still predominant pictures of scientific progress, societal emancipation, and functional differentiation that also inform Habermas' writings (LEEZENBERG, 2010, p. 95).
\end{abstract}

In the same vein, Charles Taylor's account of secularism in the context of Euro-Atlantic Christianity in A Secular Age is also assessed as normative (MAHMOOD, 2010). The focus on "Latin Christendom" and its pair, the "North Atlantic civilization", as forces of secularity also hint at its universalist claims. Even as Taylor is critical of Christianity's identification with the civilization project, he uncritically uses essentialist concepts like "primitive religion" of the "past of mankind", Karl Jaspers' "axial age" and its progressive notion of history, etc. "Perhaps what is most surprising is Taylor's consistent movement (or slippage?) 
throughout the book from the particularity of Christianity to its universalist transcendence." (MAHMOOD, 2010, p. 292). And inasmuch as EATWOT's postreligional paradigm shares in this evolutionary and essentialist directions, its inquiry into Asian religions almost automatically becomes 'Orientalist' starting from the question itself up to all its attempted responses.

\section{2 'Asianism': Asian Values Debate}

Beyond Orientalist and neo-Orientalist discourses, a distinctly 'Asian idea of Asia' started in Japan during the later part of the $19^{\text {th }}$ century. "Asia is one," declares Okakura Tenshin (1862-1913), a Japanese art historian. He claims that the 'Asiatic race' (i.e., Indian and Chinese civilizations) aspires for the 'ultimate and universal' while, in contrast, the Mediterranean and Baltic maritime peoples strive for the 'particular', for the means rather than the end (MILNER; JOHNSON, 1997, p. 1). However, another group of Japanese writers under Yukichi Fukuzawa (18351901) popularized what came to be known as "Departure from Asia" program (MIWA, 1968). He wanted to establish Japan like the European nation-states by separating itself from the tributary system of the Confucian China. But this plan was not to Europeanize Asia. It was in reality an act of confronting Europe within the terrain of its own discourse (the nation-state), as it were. It is also in this context that we can understand a latter-day Japanese ideology on the "East Asia Co-Prosperity Sphere" during World War II. It also aimed to recover the "ancient glory of the spiritual life of Asian peoples", "eschew dependence on Europe and America" and foster a "new Oriental capitalist culture" (TEIJI, 1975).

In India, two writers stand out: Vivekanda (1863-1902) and Rabindranath Tagore, the Nobel Prize-winning Indian poet. Vivekanda claims that while the West produces giants in science and politics, Asia is well-known for its giants in spirituality. All throughout his life, Tagore was devoted to the promotion of the 'spiritual civilization of the East'. In China, Sun Yat-Sen (1866-1925) launched 
his "Great Asianism" project in 1924 as he praised the Japanese victory over Russia as reawakening the hope of independence of all Asian nations from Europe (YATSEN, 2014). The 'Asian way' departs from the idea of a culturally homogenous Confucian Asia. What was aimed at was a heterogeneous and multicultural Asia consisting of independent and equal nation-states accommodating all religious, cultural and economic differences. Therefore, Sun Yat-Sen's “Great Asianism” (or Pan-Asianism) posed itself as a critique to the Japanese "East Asianism" project. In other words, even as Sun Yat-Sen's notion of Asia is essentialist, it was in fact more open to internationalism than the distinctly Japanese Confucian dream.

This same direction plays itself again in our times: the "Asian values debate". 23 The 'Asian values' proponents believe in this basic tenet - that a set of 'Asian values' is shared by peoples in the East Asian and Southeast Asian region. Lee Kuan Yew of Singapore and Mahathir Mohammad of Malaysia are two of its passionate proponents. These 'Asian values' roughly are: (1) importance of the community over the individual; (2) stress on order and harmony over personal freedom; (3) religion as an inherent dimension of society; (4) thrift, frugality and hard work; (5) family loyalty, respect for authority, etc (HOON, 2004). The proponents also believe that these mainly Confucian values are the reasons behind the 'Asian economic miracle' and the rise of 'Asian tigers'. The above enumeration is not an innocent assertion. The binaries are made in contradistinction to "values of the West' which are excessive individualism, lack of discipline, individualized religion, hedonism and low regard for authority and family. In other words, it is now Asian's turn to critique the West in an act of self-assertion. Against Fukuyama's "end of history" discourse, 'Asian values' proponents argue that capitalism can also flourish without subscribing to liberal democracy. The West should not go about imposing its version of democratic values and human rights. Liberal democracy and Western decadence, as practiced in the West today, are in fact harmful to capitalist modernity. 'Asian values' are then called upon to save it.

\footnotetext{
${ }^{23}$ For some literature on the development of this debate, see, among others, SUBRAMANIAM, 2000, p. 19-35; HARPER, 1997, p. 507517; BARR, 2000, p. 309-334.
} 
In order to assert Asian values, ancient religions in Asia are summoned to provide some religious horizons. For instance, values like family orientation, selfcultivation, and respect for authority, discipline and harmony are traced back to Confucian ethics. Confucianism is viewed in a threefold manner - as a philosophy, popular source of everyday values, and political ideology. In Singapore, for instance, academic discourse focuses on the first two backed up by the third (i.e., State ideology) (CHONG, 2002). In China, there has been an observed Confucian renaissance among the population: worship of Confucius in local governments, revival of Confucian classics and Confucian academies, popularity of traditional folk festivals. Though not as systematic as in Singapore and Malaysia, it (?) gains currency because of the tacit support of the Communist party which shifted its discourse from a hardliner Marxist ideology to notions of "harmonious society" and "peaceful rise" (CHEN, 2012). In all these cases, Confucianism has been constructed so as to counter Western influence on Asian societies - a move parallel to Orientalism, but in reverse mode. Some authors call it "Occidentalism". To take another example, going back to Islamic roots means putting up a strong resistance to the inroads of Western modernity in some Middle Eastern and Asian societies.

But the summoning of these values also runs parallel to essentialist Orientalist discourse. The Asian ideal of a "heroic revolutionary" is contrasted with the Western carefree and rootless bourgeois; the Asian faith-filled community against a Western civilization which is "all reason without a soul"; the Asian organic vision against the Western mechanical worldview, etc. (BURUMA; MARGALIT, 2005). Such movements of return to Asian religions prove no different from Milbank's and Ratzinger's project of selective recovery of Christendom as defense against the threat of plural nihilist and inimical (post)modern forces that come knocking at its gates. The Hindutva (Hindu-ness) as an ideology that defines Indian identity through Hindu values is another case in point. Articulated as an ideology in 1920s, it became popular when it was assumed by a political party (BJP). Hindutva calls upon Hindu values and marshals them against Muslims, Christians and other minorities considered as 
"invaders". The Hindutva nationalist movement is considered as rightist, fascist, and encourages violence as acts of self-defense against these foreign aggressors (ILAIAH, 1996; BIDWAI, 2008; RATAN, 1998). We recall that the EATWOT postreligional paradigm exempts Hinduism from the list of doctrinally controlling Neolithic religions. Hinduism, it says, is "a religion without truths" (EATWOT, 2012, p. 271). In fact, EATWOT's bifurcation of "religions" and "spirituality" reminds us of Geertz' dualistic and essentialist definition of religion as external symbols vs. internal motivations and meanings. Insofar as the post-religional paradigm essentializes "religion" and "spirituality" in its discourse and forgets an actual analysis of power that makes the discourse possible, it falls into the same trap as these strategic religious and cultural revivals.

\subsection{Beyond (Neo)Orientalism and Asianism}

Let me summarize the arguments made thus far. When we wanted to ask if Asia is a 'post-religional society', we first determined which 'Asia' we are talking about. We have identified two main discourses on the 'idea of Asia': neo-Orientalist Asia and Asianist Asia. The first is a Western discourse about its colonized peoples; the second is Asia's self-representation vis-à-vis its (neo)colonizers. These discourses exercise real consequences on which religions are discussed, mobilized and classified. Different as these two positions are, they in fact converge on some common glaring difficulties. ${ }^{24}$ First, both of them came to be used as ideological tools to maintain some sense of dominance over its 'other'. The Orientalist and neo-Orientalist discourse on Asia is an inherent function of the imperial and neoimperial enterprise. The imperial power needs to construct its other in a way that is profitable to the (neo)colonial project, that is, the continuous subjugation of its colonies - both in social as well as mental structures. The 'Asianist' discourse, on the other hand, has been also blamed as an ideological strategy to keep some structures of cultural and political dominance in place. Second, both positions are engaged in essentializing the other. Such a discourse forgets that all assertions of a

\footnotetext{
${ }^{24}$ For a critical assessment of the 'Asian values' discourse in the Southeast Asian context, see SOUCHOU, 2001.
} 
cultural group about itself (i.e., values, traits, identities) are constructed under specific socio-historical conditions. It is not so much the values themselves considered metaphysically and transhistorically as those social conditions that provide the key to our understanding of these realities. The Orientalist discourse freezes Asian identity as 'unchanging', 'mysterious', 'religious' - one which is not (yet) comparable with the modern Enlightenment the West was trying to promote. The 'Asianist' discourse likewise pegs Asian identity into its essentialist characteristics, while being consistent with its program of combating the onslaught of Western decadence that comes with capitalism and modernity (HOON, 2004).

The problem with these essentialized characteristics is that they become monolithic labels of what otherwise are heterogeneous Asian cultures and religious practices. For instance, we may ask if there is a real common set of values in Asia when we know that this region is a product of equally contending religious and cultural traditions (Confucian, Islamic, Buddhist, Hindu and Christian). ${ }^{25}$ Since identities and religions are essentialized against the 'other', what come to existence are binary opposites with their corresponding hierarchies - West vs. East, Christianity vs. Oriental religions, modernity vs. tradition, etc. What proves to be problematic in binary thinking is its hierarchy, that is, the assertion of one side of the pole automatically demonizes or degrades the other. Thus, while the Orientalist discourse privileges the West and denigrates the East, the 'Asianist' discourse also enthrones the so-called Oriental values and religions at the expense of other paradigms.

EATWOT's post-religional paradigm needs to be cognizant of these loopholes if it wants to effectively contribute to the analysis of religions in these changing times. As it is tentatively articulated, the theological proposal displays a sense of theoretical ambivalence. On the one hand, its evolutionary directions as seen in its commonalities with Bellah's project, the secularization thesis and post-

\footnotetext{
${ }^{25}$ Against the emphasis on authority-centeredness present in the 'Asian values' discourse, Amartya Sen, for instance, has consistently argued that the democratic tradition, tolerance, personal freedom is inherent in the tradition of Asian countries. See SEN, 1999, p. 3-17; SEN, 1997.
} 
secular discourses lead it to an Orientalist discourse of Asian religious sensibilities and essentialized views of religions and spiritualities. On the other hand, its noncumulative view of cultural evolution (i.e., the disappearance of old Neolithic religions and maybe future religions for that matter) which we assessed as parallel to Thomas Kuhn's notion of "paradigm shifts" in science gives the theologian a reflexive sensibility to the emerging but still inchoate forms of spiritualities, religious experiences and practices that proceed from and make real sense in the lives of people on the ground. But it is also this strength which turns itself into weakness when the search for the 'spiritual' and 'religious' becomes a pursuit of the essential and the universal (most often equated with the human) beyond those which it considers as the transitory forms of 'religions' (EATWOT, 2012, p. 263). ${ }^{26}$

\section{Religions: Back to the Rough Grounds}

In the end, we are thus led back to the first question: "Is Asia a postreligional society?" The query does not possess one single answer; or, if we push our established assumptions to their logical conclusions, it is impossible to answer it at all. Following Talal Asad, it is imperative to situate the inquiry on religions in the context of socio-historical conditions (movements, classes, institutions, and ideologies - all vehicles of social power) that make religious experience possible. And these power-laden contexts are complex, diverse and multiple. Only through such process can we avoid essentialist views of religion applicable to all locations and epoch. What comes to mind is an image which the neo-Marxist philosopher, Raymond Williams, uses for "art": the notion of art as "practice". Translating it to our concerns, religions are not only "mediums" - "objects, things, which men [sic] take up and arrange into particular forms to express or communicate information" like doctrines, rituals, practices defined in abstraction and isolated from the sociohistorical powers that produced them. No, religious dogmas, beliefs and practices must be inevitably seen as "social practices" by bringing them back to the social

\footnotetext{
${ }^{26}$ The EATWOT theological proposal is extra careful (and suspicious) about accepting the term "spirituality" because of its dualistic tone and the inadequacy of its definition/conceptualization. Yet its search for adequate universal definition by summoning synonyms and parallels still smacks of essentialism.
} 
processes of their "material production" (WILLIAMS, 1978, p. 163-164). Only in the context of these grounds shall we see their effectively historical meanings, development and interrelations.

Let me illustrate this point with some examples. Although the prevalent religious dualisms "transcendence-immanence", "sacred-profane", "spiritualmaterial" continue to be universalized in many discourses, the meaning of the binaries in fact does not remain constant. Some socio-historical contexts consider that the spirits can be material or the sacred does not at all mean transcendental, as evidenced by the early colonial encounters between the Spanish missionaries and Filipino 'natives'.27 While the Spanish missionaries proclaimed the traditional Catholic doctrines of God, spirits and souls as transcendent, the Filipino natives thought of them as "this-worldly". The kaluluwa (souls) of our ancestors are always with us. They also "eat" as we offer them food on their graves and on family altars on special occasions; or we send them their favorite drink or cigar on their coffins as provisions for their "journey". The nono (spirits) are not transcendental sacred figures but "indeterminate auras emanating from certain objects in nature - trees, rocks, rivers, fields, even crocodiles." (RAFAEL, 1993, p. 113). They reside with us in the same world so much so that when people urinate in the fields or pass big trees on forests, they need to ask their permission by saying "tabi po" (let us through). We can haggle and bargain with them, offer oblations but also send pleas to and coax them into granting special favors. All these tendencies are still present in contemporary Filipino spirituality. Its linguistic residues still abound: the Tagalog word for asking for forgiveness is "tawad", for instance, as it is used in sacramental confession. But this same root word also means "to bargain, haggle or to use evasions (in Spanish regatear)" (RAFAEL, 1988, p. 91-109). Such a discourse can only be understood from the perspective of pre-colonial social structures characterized by "forms of indebtedness and servitude that were transferable and negotiable" and where social positions were not fixed but

\footnotetext{
${ }^{27}$ See among others: BOLASCO, 1994, p. 219-234; RAFAEL, 1988; PERTIERRA, 1988.
} 
alterable. In these social universes, rendering tribute to the nono or kneeling down in confession was not seen as total submission to immutable transcendental power but were "ways of bargaining... plugging into a circuit of indebtedness in which one could hope to accumulate the means to shift social registers." (BOLASCO, 1994, p. 228). Of course, there were also some whose spirituality largely leaned toward the other side of the binary, i.e., the transcendent dimension. But this direction was only "particularly appealing to those 'natives' who had a special stake in the preservation of relations of inequality" - the ruling classes (the principalia). Such specific nuances as these can only be understood on the ground and are absent in the essentialist rendering and universal application of these binary relations.

The shifting meaning of purdah as religious and social practice is another example (SHEHABUDDIN, 2008). Purdah is a custom among Muslim or Hindu women of dressing in enveloped clothes or living behind curtains or separate rooms in order to segregate them from men and strangers. In dominant secular discourses, the practice has been criticised as an instrument of oppression, a way to domesticate women by limiting their movement, thus, also their agency and possibilities. On the one hand, it is an act of perpetuating male domination and reproducing gender inequality: "the male being self-reliant and aggressive, the female weak, irresponsible, and in need of protection." (WHITE, 1977). On the other hand, purdah is practiced to protect women from harassment, from being portrayed as sex objects and securing their mobility and safety in public spaces. Moreover, others think that purdah becomes an assertion of subaltern gender and cultural identities toward some heightened status and visibility in contemporary social spaces (FELDMAN, MCCARTHY, 1983). How are these discursive battles wrestled with on the ground? In Bangladesh, there are poor rural women working in factories who discard the practice neither by rejecting the Islamic injunction outright nor by exhibiting total agreement with the secularist agenda, but through re-defining purdah as "a state of mind, a purity of thought, something that they carry inside them rather than an expensive outer garment"(SHEHABUDDIN, 2008, p. 4). The same act is both a critique of gender domination in Islamic universes and the pretensions of class in modern societies done through a clever 
reinterpretation of Islamic theology. In the process, these poor women have navigated dexterously between the Islamist and secularist agenda by reinventing themselves as "pious Muslim women", but also securing spaces necessary for the survival of their families. This analysis is not quite accessible in the easy essentialist application of "modern-traditional" or "secular-religious" binary categories. In this actual negotiation of power on the ground, the modern is not necessarily secular nor the religious always traditional.

\section{Conclusion}

I would like to conclude with a famous passage from Ludwig Wittgenstein:

We have got on to slippery ice where there is no friction and so in a certain sense the conditions are ideal, but also just because of that, we are unable to walk. We want to walk, so we need friction. Back to the rough ground! (WITTGENSTEIN, 1958, p. 46).

Wittgenstein was critiquing the crystalline purity of logic that does not work in real life. I am transposing its relevance to the study of religions. ${ }^{28}$ Essentialist and universalist accounts detach concepts from the grounds of their material production. On the one hand, they do not produce friction. These concepts and definitions can enter and leave different historical epochs intact and unscathed. On the other hand, they are also deceptive and ineffective. With them, to use the words of Asad, "we shall not make much headway in understanding agency." (ASAD, 1993, p. 167). Without friction, we cannot walk. But we want to walk. So back to the rough grounds!

\footnotetext{
${ }^{28}$ I have employed this central text elsewhere in order to propose a viable theological methodology. Cf. PILARIO, 2005.
} 


\section{REFERENCES}

ANDERSON, Perry. Lineages of the absolute State. London: Verso, 1979.

ARMSTRONG, Karen. The great transformation: the beginning of our religious traditions. New York: Anchor Books, 2007.

ASAD, Talal. Anthropological conceptions of religion: reflections on Geertz. Man, London, New Series, v. 18, n. 2, p. 237-259, Jun. 1983.

ASAD, Talal. Formations of the secular: Christianity, Islam, modernity. Stanford, CA: Stanford University Press, 2003.

ASAD, Talal. Genealogies of Religion: Discipline and reasons of power in Christianity and Islam. London: John Hopkins University Press, 1993.

ASAD, Talal. Modern power and the reconfiguration of religious traditions. Interview by Saba Mahmood. SEHR, v. 5, n. 1, February, 1996. Available at:

<http://web.stanford.edu/group/SHR/5-1/text/asad.html>. Access on: Oct. 10, 2014.

BARR, Michael. Lee Kuan Yew and the 'Asian Values' Debate. Asian Studies Review, Oxoford, vol. 24, no. 3, p. 309-334, 2000.

BECKFORD, James. Public Religions and the Post-secular: Critical Reflections. Journal of the Scientific Study of Religion, Hoboke, vol. 51, no.1, p. 1-19, 2012.

BELLAH, Robert N. Beyond Belief: Essays on Religion in a Post-Traditionalist World. Berkeley, CA: University of California Press, 1991.

BELLAH, Robert N. Nothing is ever lost: an interview with Robert Bellah. In: BELLAH, Robert N. Beyond belief: essays on religion in a post-traditionalist world. Available at: <blogs.ssrc.org/tif/2011/o9/14/nothing-is-ever-lost/>. Access on: Oct. 06, 2014.

BELLAH, Robert N. Religion in human evolution: from the paleolithic to the axial age. Cambridge, MA: Harvard University Press, 2011.

BELLAH, . Robert N. Religious Evolution. American Sociological Review, Albany, vol. 29, no. 3, p. 358-374, 1964. Available at:

<http://www.hartfordinstitute.com/Bellah/Religious\%20Evolution\%20by\%2oRobert\%20

N.\%20Bellah\%20--

\%20American\%20Sociological\%20Review\%2029,\%20no.\%203,\%20pp.\%20358-

374..pdf>. Access on: Oct. 06, 2014.

BELLAH, Robert N.; JOAS, Hans (Ed.). The Axial Age and its Consequences.

Cambridge, MA: Belknap Press, 2012.

BERGER, Peter. The Desecularization of the World: A Global Overview. In: BERGER, Peter (Ed). The Desecularization of the World: Resurgent Religion and World Politics. Washington, DC: The Ethics and Public Policy Center, 1999. p. 1-18. 
BERGER, Peter. The rumor of angels. Garden City, NY: Doubleday Books, 1969.

BERGER, Peter. The sacred canopy: elements of a sociological theory of religion. Garden City, NY: Doubleday Books, 1967.

BIDWAI, Praful. Confronting the reality of Hindutva terrorism. Economic and Political Weekly, Mumbai, vol. 43, no. 47, p. 10-13, Nov. 2008.

BIRCH, David; SCHIRATO, Tony; SRIVASTAVA, Danjay. Asia: Cultural Politics in the Global Age. New York: Palgrave, 2001. p. 1-13.

BOLASCO, Mario. Notes on revolts and popular religiosity in the Philippines. [1989]. In: BOLASCO, Mario; DE LA TORRE, Edicio. Points of departure: essays on

Christianity, power and social change. Manila: St. Scholastica's College, 1994.

BURUMA, Ian; MARGALIT, Avishai. Occidentalism: the west in the eyes of its enemies. New York: Penguin Books, 2005.

CALHOUN, Craig; MENDIETA, Eduardo; VANANTWERPEN, Jonathan. Habermas and Religion. London: Polity Press, 2013.

CASANOVA, José. A secular age: dawn or Twilight. In: WARNER, Michael; VANANTWERPEN, Jonathan; CALHOUN, Craig (Ed.). Varieties of Secularism in a Secular Age. Cambridge, MA: Harvard University Press, 2010. p. 265-281.

CASANOVA, José. Exploring the postsecular: three meaning of the 'secular' and their possible transcendence. In: CALHOUN, Craig et al. (Ed.). Habermas and religion. London: Polity Press, 2013. p. 27-48.

CASANOVA, José. Religion, the axial age, and secular modernity in Bellah's theory of religious evolution. In: BELLAH, Robert N.; JOAS, Hans (Ed.). The axial age and its consequences. Cambridge, MA: Harvard University Press, 2012. p. 191-221.

CASANOVA, José. Rethinking secularization: a global comparative perspective. The Hedgehog Review, spring/ summer 2006. Available at: < http://www.iascculture.org/THR/archives/AfterSecularization/8.12CCasanova.pdf >. Access on: Oct. 10, 2014 .

CASANOVA, José. Secularization Revisited: A Reply to Talal Asad. In: SCOTT, David; HIRSCHKIND, Charles. Powers of the Secular Modern: Talal Asad and his Interlocutors. Stanford, CA: Stanford University Press, 2006. p. 12-30.

CASANOVA, José. The secular and secularism. Social Research, New York, v. 76, n. 4, p. 1049-1066, winter 2009. 
CHEN, Yong. Renewing Confucianism as a living tradition in the 21st century China: reciting classics, reviving academies, and restoring rituals. In: GIORDAN, Giuseppe; PACE, Enzo (Ed.). Mapping religion and spirituality in a postsecular world. Leiden: Brill, 2012. p. 63-84.

CHONG, Terence. Asian values and Confucian ethics: Malay Singaporeans' dilemma. Journal of Contemporary Asia, Dept. of Sociology, University of Warwick, v. 32, n. 3, p. 394-406, 2002. Available at: <http://www.olemiss.edu/courses/pol337/chongto2.pdf > . Access on: Oct. 28, 2014

DAVIE, Grace. Believing without belonging: just how secular is Europe. Pew Research Center, Washington. December 5, 2005. Available at:

<http://www.pewforum.org/2005/12/05/believing-without-belonging-just-how-secularis-europe/>. Access on: Oct. 10, 2014.

DAVIE, Grace. Religion in Britain since 1945: believing without belonging. Oxford: Blackwell, 1994.

DAVIE, Grace. Religion in modern Europe: a memory mutates. Oxford: Oxford University Press, 2000.

EATWOT International Theological Commission. Towards a post-religional paradigm: a theological proposal. Voices, v. 35, n. 1, 2012. Available at:

<http://internationaltheologicalcommission.org/VOICES/VOICES-2012-

1TheologicalProposalMultilingual.pdf>. Access on: Oct. 05, 2014.

ERLANDSON, Sven. Spiritual But Not Religious: A Call To Religious Revolution In America. San Jose: Writers' Showcase, 2000.

FELDMAN, Shelley; MCCARTHY, Florence. Purdah and Changing Patterns of Social Control among Rural Women in Bangladesh. Journal of Marriage and Family, Oxford, v. 45, no. 4, p. 949-959, 1983.

FULLER, Robert. Spiritual but not Religious: Understanding Unchurched America. Oxford: Oxford University Press, 2001.

GEERTZ, Clifford. Religion as a cultural system. In: GEERTZ, Clifford. Interpretation of cultures. New York: Basic Books, 1973. p. 87-125.

GREELY, Andrew. Religion in Europe at the End of the Second Millennium. New Brunswick: Transaction Publishers, 2003.

HABERMAS, Jürgen. An awareness of what is missing. In: HABERMAS, Jürgen; BRIESKORN, N.; SCHMIDT, J. (Ed.). An awareness of what is missing. Cambridge: Polity Press, 2010 p. 15-24.

HABERMAS, Jürgen. Between naturalism and religion. Cambridge: Polity Press, 2008. 
HABERMAS, Jürgen. Notes on a post-secular society. New Perspectives Quarterly, Los Angeles, vol. 25, no. 4, p. 17-29, fall 2008.

HABERMAS, Jürgen. Pre-political Foundations of the Democratic Constitutional State. In: HABERMAS, Jürgen; RATZINGER, Joseph. The dialectics of secularization: on religion and reason. San Francisco: Ignatius Press, 2006. p. 19-47.

HABERMAS, Jürgen; RATZINGER, Joseph. The dialectics of secularization: on reason and religion. San Francisco: Ignatius Press, 2006.

HARPER, T. N. Asian Values and the Southeast Asian Histories. The Historical Journal, [s.l.], vol. 40, no. 2, p. 507-517, 1997.

HAY, Stephen. Europe: The Emergence of an Idea. Edinburgh: Edinburgh University Press, 1957.

HEGEL, G. F. W. The philosophy of history. [1899]. Intro. C. J. Friedrich, Trans. J. Sibree. Mineola, New York: Dover Publications, 1956.

HERVIEU-LÉGER, Danièle. Religion und Sozialer Zusammenhalt in Europa. Transit: Europäische Revue, Frankfurt, n. 26, p. 101 -119, summer 2004.

HOON, Chang Yau. Revisiting the Asian values argument used by Asian political leaders and its validity. The Indonesian Quarterly, Jakarta, vol. 32, no. 2, p. 154-174, 2004.

HUI, Wang. An Asia that isn't the East: a new way to see world history. Le monde diplomatique, Paris, February 05, 2005. Available at: <http://www.global policy.org/nations/sovereign/integrate/ 2005/o2asia.htm>. Accessed in: Oct. 10 ${ }^{\text {th }}, 2014$.

HUI, Wang. Imagining Asia: a genealogical analysis. Available at: <hhtp://www.cscsban.org/html/Wang\%20\%Hui2oFull\%20Paper.htm>. Accessed in: Jul. $17^{\text {th }}, 2006$.

ILAIAH, Kancha. Why I am not a Hindu: a Sudra critique of the Hindutva philosophy, culture and economy. Calcutta: Bhatkal and Sen, 1996.

IWAMURA, Jane Naomi. Virtual Orientalism: Asian Religions and American Popular Culture. Oxford and New York: Oxford University Press, 2011.

JASPER, Karl. The origin and goal of human history. New Haven, CT: Yale University Press, 1953.

JASPERS, Karl. Way to wisdom: an introduction to philosophy. New Haven, CT: Yale University Press, 1954.

JOAS, Hans. Interview with Robert Bellah. The Hedgehog Review, Chalottesville, vol. 14, no. 2, summer 2012. Available in: <http://iascculture.org/THR/THR_article_2012_Summer_Interview_Bellah.php $>$. Accessed in: Oct. $16^{\text {th }}, 2014$. 
KANT, Immanuel. Kant: Political Writings. Cambridge: Cambridge University Press, 1991.

KEPPEL, Gilles. The Revenge of God: The Resurgence of Islam, Christianity and Judaism in the Modern World. University Park, PA: Pennsylvania State University Press, 1994.

KING, Richard. Orientalism and religion: postcolonial theory, India and the 'mystic east'. London: Routledge, 1999.

KUHN, Thomas. The structure of scientific revolutions. 2nd ed. Chicago: University of Chicago Press, 1970.

LEEZENBERG, Michel. How ethnocentric is the concept of the postsecular. In: MOLENDIJK, Arie et al. (Ed.). Exploring the postsecular: the religions, the politics and the urban. Leiden: Brill, 2010. p. 91-112.

LOUGHLIN, Gerard. Christianity at the end of the story or the return of the masternarrative. Modern Theology, [s.l.], v. 8, n. 4, p. 365-384, 1992.

MAHMOOD, Sahba. Can secularism be other-wise? In: WARNER, Michael; VANANTWERPEN, Jonathan; CALHOUN, Craig (Ed.). Varieties of Secularism in a Secular Age. Cambridge, MA: Harvard University Press, 2010. p. 282-299.

MARTIN, David. Pentecostalism: The World Their Parish. Oxford: Blackwell, 2002.

MCINNES, Niel. Orientalism: the evolution of a concept. The National Interest, December 22, 1998. Available at: <http://nationalinterest.org/article/orientalism-theevolution-of-a-concept-765>. Accessed in: Oct. 30 2014.

MCLELLAN, Gregor. Spaces of post-secularism. In: MOLENDIJK, Arie; BEAUMONT, Justin; JEDAN, Christoph (Ed.). Exploring the post-secular: the religious, the political and the urba. Leiden: Brill, 2010. p. 52-56.

MILBANK, John. A closer walk on the wild side. In: WARNER, Michael; VANANTWERPEN, Jonathan; CALHOUN, Craig (Ed.). Varieties of Secularism in a Secular Age. Cambridge, MA: Harvard University Press, 2010. p. 54-82.

MILBANK, John. Theology and social theory. 1990. Oxford: Blackwell, 2006.

MILBANK, John. Theology and Social Theory. 2nd ed. Hoboken: Wiley-Blackwell, 2006. p xii.

MILBANK, John; OLIVER, Simon (Ed,). The Radical Orthodoxy Reader. London: Routledge, 2009.

MILBANK, John; PICKSTOCK, Catherine; WARD, Graham (Ed.). Radical Orthodoxy: A New Theology. London: Routledge, 1998. 
MILNER, Anthony; JOHNSON, Deborah. The idea of Asia. In: INGLESON, John (Ed.). Regionalism, subregionalism and APEC. Clayton: Monash Asia Institute, 1997. p. 119.

MIWA, Kimitada. Fukusawa Yukichi's 'Departure from Asia'. In: SKRZYPEZAK, E. Japan's Modern Century. Tokyo: Sophia University, 1968.

OPPENHEIMER, Mark. Examining the Growth of 'Spiritual but not Religious'. The New York Times, New York, July 18, 2014. Available at: <http://www.nytimes.com/2014/o7/19/us/examining-the-growth-of-the-spiritual-butnot-religious.html>. Access on: Oct. 10, 2014.

PILARIO, D. F. Back to the rough grounds of praxis: exploring theology with Pierre Bourdieu. Leuven: Peeters, 2005.

PILARIO, D. F. Spirituality and Postmodernity in Asia. INSTITUTE OF SPIRITUALITY IN ASIA. Spirituality of Authentic Witness in Postmodern Asia. Quezon City: Institute of Spirituality in Asia, 2007. p. 24-53.

PERTIERRA, Raul. Religion, Politics and Rationality in a Philippine Community. Quezon City: Ateneo de Manila University Press, 1988.

RAFAEL, Vicente L. Contracting colonialism: translation and Christian conversion in Tagalog society under early Spanish rule. Durham: Duke University Press, 1993.

RATAN, Sudha. Hindutva: the shaping of a new 'Hindu' identity. Southeastern Political Review, [s.l.], v. 26, n. 1, p. 201-217, 1998.

RATZINGER, Joseph. Faith and the future. Trans. Franciscan Herald Press. San Francisco: Ignatius Press, 2009.

SAID, Edward. Orientalism: western conceptions of the Orient. 1978. London: Penguin Books, 1995.

SEN, Amartya. Democracy as a universal value. Journal of Democracy, [s.l.], v.10, n. 3, p. 3-17, Jul. 1999.

SEN, Amartya. Human rights and Asian values. The New Republic, [s.l.], v. 217, n. 2-3, p. 33, July $14^{\text {th }}, 1997$.

SHEHABUDDIN, Elora. Reshaping the holy: democracy, development and Muslim women in Bangladesh. New York: Columbia University Press, 2008.

SOUCHOU, You (Ed.). House of Glass: Culture, Modernity and the State in Southeast Asia. Singapore: Institute of Southeast Asian Studies, 2001.

SUBRAMANIAM, Surain. The Asian Values Debate: Implications for the Spread of Liberal Democracy. Asian Affairs, London, vol. 27, no. 1, p. 19-35, 2000. 
REICH, Robert. Introduction. In: CANNAN, Edwin (Ed.). SMITH, Adam. The wealth of nation. New York: Modern Library, 2000.

SMITH, Adam. The wealth of nation. New York: Modern Library, 2000.

TAYLOR, Charles. A secular age. Cambridge, MA: Harvard University Press, 2007.

TEIJI, Yabe. Greater East Asia co-existence sphere. In: LIBRA, J. C. (Ed). Japan's greater East Asia co-prosperity sphere in World War II: selected readings and documents. Kuala Lumpur: Oxford University Press, 1975.

THOMAS, Scott. The Global Resurgence of Religion and the Transformation of International Relations. New York: Palgrave Macmillan, 2005.

TOYNBEE, Arnold. Study of History, vol. 8. London: Oxford University Press, 1954.

TURNER, Bryan. The Sociology of Religion. London: SAGE Publications, 2011, 285301.

TURNER, Bryan. Weber and Islam. London: Routledge, 1974.

WARNER, Michael et al. Editors' introduction. In: WARNER, Michael;

VANANTWERPEN, Jonathan; CALHOUN, Craig (Ed.). Varieties of Secularism in a

Secular Age. Cambridge, MA: Harvard University Press, 2010. p. 22-23.

WARNER, Michael; VANANTWERPEN, Jonathan; CALHOUN, Craig (Ed.). Varieties of Secularism in a Secular Age. Cambridge, MA: Harvard University Press, 2010

WARNER, Rob. Secularization and its discontents. London: Continuum, 2010.

WEBER , Max. Economy and society: an outline of interpretive Eeconomy. Berkeley, CA: University of California Press, 1978.

WEBER, Max. From Max Weber: essays in sociology. 1st ed. London: Routledge, 1991.

WHITE, Elizabeth. Purdah. Frontiers: A Journal of Women Studies, [s.l.], v. 2, p. 3142, 1977.

WILLIAMS, Raymond. Marxism and literature. London: Oxford University Press, 1978.

WITTGENSTEIN, Ludwig. Philosophical Investigations.[1953]. 2nd ed. Trans. G.E.M. Anscombe. London: Blackwell, 1958.

WUTHNOW, Robert. Rediscovering the Sacred: Perspectives of Religion in Contemporary Society. Grand Rapids, MI: Williams E. Eerdsmann, 1992.

YAT-SEN, Sun. Speech on pan-asianism. Available at:

<http://www.answer.com/topic/sun_yat_sen_s_speech_on_pan-asianism >.Access on: Oct. 10, 2014. 